J T Dreyer

\section{PROBLEMY OBOZÓW PRACY W CHINACH}

James D. Seymour i Richard Anderson, Nowe duchy, stare duchy: wiezienia i obozy pracy w Chinach, Armok, N.Y.M.E. Sharpe, 1998.

„Porozrzucane szkielety leża Na bezkresnym obszarze Qinghai. Nowe duchy krzycza ",o niesprawiedliwe". Stare duchy po prostu placza".

— Tu Fu (712-770)

Tu Fu napisał te słowa trzynaście wieków temu. Pomimo wielu wydarzeń, które miały miejsce od tamtego czasu, Qinghai ciągle uważane jest za miejsce kary i odosobnienia. Nauczyciele w Chinach kontynentalnych żartobliwie przestrzegają swoich młodych podwładnych, że nieprzepisowe lub nieostrożne zachowanie może doprowadzić do życia w odosobnieniu w Qinghai. W kraju i na świecie prowincja ta stała się metafora przerażajạcych laogai: chińskich gułagów. Dlatego gorzkie słowa Tu Fu są trafnym tytułem rozprawy Seymoura i Andersona o więzieniach północno-zachodnich Chin, szczególnie od połowy lat osiemdziesiątych do połowy lat dziewięćdziesiątych.

Autorzy, wykładowcy i aktywiści ruchu obrony praw człowieka, prowadzą badania nad system karnym trzech sąsiadujących ze sobą prowincji na północnym zachodzie: Gansu, Qinghai i Xinjiang. Zamierzali oni przygotować ściśle empiryczną rozprawę naukową, a nie dyskutować o teorii więziennictwa czy też rozwijać nauki społeczne. Osiągnięcie obiektywizmu w tego rodzaju badaniach, wyzwalających silne emocje, pociąga za sobą ryzyko rozgniewania zarówno zachodnich działaczy ruchu praw człowieka, którzy uważają, że system ten jest bardzo zły, jak i tych, którzy starają się nadać blasku wizerunkowi Chińskiej Republiki Ludowej (ChRL), twierdząc, że jest to przełom w więziennictwie. Seymour i Anderson radzą sobie $\mathrm{z}$ tymi zadaniami. Jest to świetna rozprawa, chociaż na ponury temat.
Głównym zainteresowaniem autorów jest chiński reżim więzienny „laogai" lub system „poprawy poprzez pracę", lecz interesuje ich również „laojiao"- reedukacja poprzez pracę. Ta ostatnia jest najsurowszym rodzajem chińskiej kary administracyjnej, i przeznaczona jest dla tych, których zachowanie oscyluje pomiędzy „zbrodnią a błędem". Do skazanych na laojiao należą włóczędzy, drobni kryminaliści i przestępcy polityczni. Oczywiście, wszyscy pochodzą z terenów miejskich. Do 1979 roku wyrok skazujące na laojiao mogły być przedłużane, a warunki były tak złe, jak te panujące w laogai. Od tamtej pory wyroki były bardziej określone i generalnie krótsze.

Idea laogai wzięła sie z wiary Mao Zedonga w to, że członkowie wrogiej klasy mogą zmienić się w produktywnych i odpowiedzialnych obywateli nowego socjalistycznego państwa. System ten więc ma swoje korzenie bardziej w teorii politycznej, niż w prawie karnym i w rzeczywistości dopiero teraz większość więźniów znajduje się tu z powodów, które mają mały związek z polityką lub pochodzeniem klasowym. Na naradzie w 1951 roku zdecydowano, że najlepiej bẹdzie oczyścić wschodnie Chiny z niepożądanych politycznie elementów, takich jak właściciele ziemscy i członkowie grup antykomunistycznych, aby nigdy nie mogli odbudować starego, reakcyjnego porządku politycznego. Północno-zachodnie prowincje nie podjeły decyzji, by przyjać tych osobników: decyzja została podjęta odgórnie. Przewiezieni na odległy i słabo rozwinięty północny zachód, ci pariasi mogli zrehabilitować się, budując infrastrukturę terenu. Przy ponurym klimacie i braku komunikacji, ucieczka była mak) prawdopodobna. Więźniowie miel produkować jedzenie dla siebie i swoich strażników. Celem ich działań jednak nie było zwykła samowystarczalność, lecz wspólny dobrobyt: biedne prowincje miały stać się bogate, a łotry zmienić się w politycznie godnych zaufania obywateli.

Mając na myśli tak szlachetny cel, zadziwiające jest, że pekińska opinia publiczna przedstawiła więzienia jako życzliwe instytucje, gdzie „niewielka grupka" reakcjonistów i masy ludzi, których oszukiwali, rehabilitują się pod opieką kochających strażników. Analfabetów uczono pisać i czytać, uczono ich też zawodów, przydatnych do późniejszego życia. Zagraniczni goście, oprowadzani po modelowych więzieniach w pełni potwierdzili te doniesienia.

Z drugiej strony, zaczynają krążyć przerażające opowieści o torturach, sadystycznym traktowaniu i powolnej śmierci głodowej. Odważna i szcześliwa garstka, która uciekła na Zachód, szczegółowo opisała te okrucieństwa. Wśród najsłynniejszych są: „Laogai — chiński gułag" Harry'ego Wu (Boulder: Westview Press, 1992) i „Czerwoni w zębach i pazurach: 26 lat w chińskim komunistycznym więzieniu" (New York, Grove Press, 1994). Autor tej ostatniej przeżył kilka lat w wysuszonej studni, gdzie co jakiś 
czas spuszczano mu na sznurku jedzenie i tonął w nieczystościach. Przeżył, ale ma trwałe fizyczne uszkodzenia ciała.

Badania autorów, oparte na wizytach w więzieniu, wywiadach z więźniami, oficjalnych danych, raportach wewnętrznych i tajnych dokumentach przedstawiają system, nie pasujący do tych skrajności. Co więcej, pomimo formalnego nadzoru ze strony Ministerstwa Sprawiedliwości w Pekinie i chęci ujednolicenia systemu, w trzech badanych prowincjach rozwinął się on w całkowicie inny sposób.

System więzienny w Gansu jest najbardziej zrozumiały ze wszystkich. Jego władze normalnie przekazują informacje dotyczące liczby więźniów skazanych co roku i rodzajów przestępstw, za jakie zostali skazani. Dzieje się tak, gdyż więzienia w Gansu, w odróżnieniu od więzień w Qinghai i Xinjiang przyjmują tylko własnych skazanych. Ponieważ więźniowie nie są znikąd przysyłani, nie obowiązuje tajemnica państwowa. Autorzy szacują liczbę skazanych w Gansu na 125 do 130-tu osób na 100 tysięcy, trochę poniżej przecietnej w ChRL. Pomimo że większość więźniów musi pracować, ich wymuszona praca wynosi mniej niż $0,1 \%$ produkcji całej prowincji. Aktualne informacje, dotyczące liczby więźniów politycznych i religijnych były nieosiągalne, ale prawdopodobne jest, że niektórzy muzułmanie, Tybetańczycy i chrześcijanie zostali uwięzieni z powodów religijnych i politycznych.

Wyjątkowość Xinjiang polega na posiadaniu nie jednego, lecz dwóch systemów więziennictwa. Pierwszy to standardowy laogai, który podlega Ministerstwuu Sprawiedliwości w Pekinie, a więźniami są przeważnie mieszkańcy prowincji. Drugi system jest prowadzony przez xinjiangsld. Korpus Produkcyjny i Budowlany [Production and Construction Corpse PCC] zwany też bingtuan. Korpus ten podłoga władzom wojskowym w Lanzhou, które jest stolicą prowincji Gansu, ale ponieważ Lanhzou jest daleko, Korpus ten posiada pewna autonomie.

Motto oddziałów, które utworzone zostały na początku lat 50-tych brzmi: ,ze strzelbą na jednym ramieniu, z motyką na drugim". Oddziały te miały bronić Xinjiang przed radzieckimi wpływami, thumić ruchy niepodległościowe wśród stanowiących większość ludności prowincji muzułmanów pochodzenia tureckiego, i rozwijać potencjał ekonomiczny prowincji.

Od więźniów, podlegającym systemowi karnemu PCC oczekuje się, że będą pomagać w tych wszystkich wysiłkach. W większości więźniowie, tak jak ich strażnicy, są Chińczykami Han. Są też zatwardziałymi kryminalistami, przysłanymi z innych prowincji, aby odsiedzieć długie wyroki. Jednocześnie może przyjechać od piecciuset do tysiaca ludzi, wysłanych z jednej tylko prowincji lub miasta. Pomimo iż więźniowie są szybko rozsyłani w różne miejsca, uważają się za grupę i w różny sposób usiłują utrzymać ze sobą kontakt. Ze względu na ich pochodzenie i mizerne szanse na uwolnienie, ludzie ci mogą być agresywni. Ich strażnicy zachowują się podobnie.

Jednym z efektów tego systemu jest to, że skazani przewodzą skazanym. Niektórzy więźniowie, przeważnie ci z dominującym charakterem stają się więziennymi szefami i rządzą innymi skazańcami za przysługi typu lepsze jedzenie i łatwiejsza praca. Stosują przy tym często barbarzyńskie metody. Zdarzają się też tacy, którzy próbują uciekać. Ponieważ większość prac odbywa się na zewnatrz, ucieczki przeważnie polegaja na opuszczeniu miejsca pracy niż na klasycznej ucieczce w stylu hollywoodzkim. Sama ucieczka nie jest trudna, lecz trudne warunki klimatyczne oznaczają, że przeżycie i dojście do miejsca zamieszkałego przez ludzi jest znacznie większym problemem. Czasem się jednak udaje. W jednym $\mathrm{z}$ przypadków skazany znalazł niestrzeżony samochód urzędnika i poprostu nim odjechał.

$\mathrm{Na}$ początku lat dziewięćdziesiątych administratorzy więzień doszli do wniosku, że coś trzeba zrobić z narastającym problemem ucieczek. Jednym ze sposobów było odbieranie więźniom butów. Innym było chodzenie więźniów trójkami. Teoretycznie, nikt nie mógł niczego zrobić sam, nawet pójść do latryny. Jeżeli jeden człowiek uciekł lub zachował się nieodpowiednio, pozostała dwójka była pociągana do odpowiedzialności. Z kolei ci, którzy donosili na innych byli nagradzani. Te metody doprowadziły do ograniczenia ucieczek do poziomu tolerowanego przez administrację.

Głównym problemem w laogai prowincji Xingjiang jest zapewnienie odpowiedniej ilości jedzenia. Nawet strażnicy mają głodowe porcje, co powoduje kradzież zapasów, przeznaczonych dla więźniów. Rodziny więźniów są proszone o datki. Były więzień opowiadał, jak jeden $z$ robotników znalazł i zabił pechowego kota. Strażnicy zjedli ciało, szefowie skórę, a więźniowie nie dostali nic.

Korupcja jest zatrważająca. Przy założeniu, że nie ma żadnych premii za dobrą pracę, nie jest dziwne, że wydajność ekonomiczna spada. Jedno ze źródeł podaje, że okoliczne cywilne gospodarstwa rolne są wydajniejsze o 30\%, niż farmy więzienne. Warunki są straszne, szczególnie dla więźniów pracujących w kopalniach uranu i azbestu.

Biorąc pod uwagę kiepską wydajność laogai i trudności z więźniami, trzeba zadać pytanie, czemu prowincja zgadza się przyjmować więźniów z zewnątrz. Zaludnienie więzień w Xingjiang zaczęło się zmniejszać w latach siedemdziesiątych i osiemdziesiątych. W 1983 roku rząd centralny rozpoczął ogólnokrajową akcję zwalczania przestępczości. Wzrosła liczba skazanych, a więzienia w Xingjiang były nie wykorzystane. Pekin zgodził się wnieść jednorazową dotację w wysokości $500 \mathrm{mln}$ juanów (60.5 mln USD), aby prowincja zaczęła przyjmować więźniów. Za wywożenie więźniów pro- 
wincja otrzymywała dodatkowe 10 tys. juanów (1220 USD) za każdego, a PCC zgodziła się zająć wszystkimi szczegółami przeniesienia.

Ten pozornie doskonały układ, przynoszący zyski obydwu stronom, w praktyce wcale nie był taki dobry. Skoro suma 10 tys. juanów wypłacana była prowincji, PCC nie miała zamiaru trzymać więźniów do końca wyroku, ponieważ zarabiała na ich wcześniejszym uwolnieniu. Miejscowi urzędnicy, którzy cieszyli sie 2 pozbycia „łobuzów", po paru latach znowu sie z nimi spotykali. W Xingjiang panowało niezadowolenie: Ujgurzy i Kazachowie byli wściekli z powodu coraz większej ekspansji Hanów na ich ziemie.

Prowincja Qinghai, podobnie jak Xinjiang, przyjęła dużą liczbę więźniów spoza swego obszaru.

Epicentrum „chińskiego gułagu" jest Haixi, nazwa ta oznacza „na zachód od morza", lub inaczej „na zachód od dużego jeziora", które wchodzi w skład samej nazwy. Samo słowo Haixi łączy w sobie elementy odosobnienia i oddalenia. Już od czasów starożytnych, Państwo Środka uważało się za otoczone czterema morzami, a ci, którzy mieszkali za morzem byli uważan za „ludzi zza płotu". Ludność regionu Haixi Dulan składa się w $18 \%$ ze skazańców, najwięcej z całego kraju.

Jednak już w latach osiemdziesiątych władze Qinghai, podobnie jak władze innych rejonów Chin, postanowiły zacząć czerpać zyski ze swojej działalności. Więzienia nie były dochodowe, zaczęto więc je zmniejszać. Nie chodziło tylko o kwestie finansowe - lokalnym przywódcom nie podobało się to, że prowincja była uważana za gułag. Byli przekonani, że wolne miejsca w więzieniach Qinghai doprowadzą do nacisku ze strony Pekinu na przyjęcie skazanych z zewnątrz. Nie chcieli już przyjmować takich ludzi, w odróżnieniu od prowincji Xinjiang. Qinhai postanowiła wykorzystać wolne miejsca w laogai, wysyłając tam okolicznych ludzi, których przestępstwa pozwoliłyby jedynie zesłać ich do laojiao. We wschodniej nadbrzeżnej prowincji Zhejiang, były wolne miejsca $\mathrm{w}$ laojiao, a brakowało w laogai. Przez to, ludzie, skazani na laogai trafiali do laojiao. W obu przypadkach korzyść była postawiona ponad prawem karnym.

Decyzja władz prowincji, aby zmniejszyć rozmiary więziennictwa w Qinghai i wykorzystać ziemię w bardziej produktywnym celu była w sprzeczności z celami zarządu laogai. W 1998 roku zarząd zażądał w sądzie odszkodowania za ziemię, na której miała stanąc tama. Zarząd przegrał, po czym prowincja zlikwidowała jednostki, zaangażowane $\mathrm{w}$ proces i wyłączyła zarząd z nowych, obiecujących gałęzi przemysłu, takich jak produkcja prądu elektrycznego i produkcja chemikaliów. Zarząd usiłował potem poprawić swoją pozycję, inwestując, z dobrymi wynikami, w rolnictwo. Obozy Haixi należą do najnowocześniejszych i najbardziej produktywnych wśród chińskich laogai. Tylko jeden obóz Xiangride produkuje trzy razy więcej zboża niż wszystkie farmy, znajdujące się pod zarządem Gansu.
Podsumowując uzyskane dane, Seymour i Anderson twierdzą, że w więzieniach w Qinghai panują najlepsze warunki, najgorsze zaś w Xinjiang. Uważają, że jedynie w Tybecie więźniowie żyją w gorszych warunkach. Pierwotne założenia ich twórców nie spełniły się, więzienia nie przynoszą dochodów. Tymczasowi zarządcy więzień martwią się tym, niektórzy nawet zaapelowali do rządu centralnego o opracowanie jakiejś polityki, która miałaby zrekompensować im oddalenie od rynku i ograniczony dostęp

do surowców.

Co do liczby więźniów, autorzy oceniają ją na około $2 \mathrm{mln}$, czyli znacznie mniej niż wcześniej twierdził Harry Wu. Proporcjonalnie do liczby mieszkańców Chin wypada 166 więźniów na 100 tysięcy mieszkańców; jest to niewiele. Seymour i Anderson uważają, że to nie rozmiar systemu więziennictwa jest przerażający, tylko to, co dzieje się za murami. W ciągu ostatnich lat warunki nieco się poprawily, ale zupetnie nie szanuje się praw człowieka. W laogai nie ma też żadnych gai czyli reform. Więźniowie ciągle stawiają opór. Nie przyznają się do winy, nie chcą się rehabilitować, a także angażują się $\mathrm{w}$ przestępczą działalność, jeszcze będąc w więzieniu. Wzajemne systemy ostrzegania też już nie są skuteczne.

Seymour i Anderson są również przerażeni faktem, że wielu więźniów w ogóle nie powinno znaleźć się w więzieniu. Jest to wina wielu czynników. Dużą rolę w systemie więziennym odgrywa korupcja i lokalny protekcjonizm. Sędziowie mają przeważnie niewystarczające wykształcenie, procedury prawne krępują działania prawników, a procesy są wysoko upolitycznione. Zdania w rodzaju: „przestraszyć lub zniechęcić ludzi" przeważnie oznaczają „,zadowolić sekretarza partii", który może manipulować bez trudu procesami sądowymi. Ponadto, wbrew oficjalnym zapewnieniom o humanitarnym traktowaniu więźniów, nagminne są przypadki fizycznego maltretowania i brutalnego wyzysku.

Wskaźniki przestępczości w Chinach wzrastają. Okres władzy Mao, z jego niemal powszechnie panującą biedą i minimalnymi motywami do popełnienia zbrodni skończył się na zawsze: dla wielu ludzi korzyści, które można wyciągnąć z nielegalnej działalności przewyższają ryzyko ujęcia. W ChRL narasta też poważny problem używania narkotyków. Te czynniki rzucają cień na kolejny wzrost liczby więźniów, z którymi nie radzi sobie aktualny chory system. Być może, to są właśnie te nowe duchy z poematu Tu Fu.

June Teufel Dreyer jest profesorem nauk politycznych na uniwersytecie w Miami w Coral Gables.

Przedruk z Free China Review, vol. 48, nr 10 (Oct. 1998). Tłum.: Karolina Linda Potocka 
